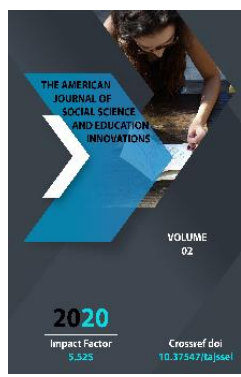

\title{
Abu Mansur Al-Moturidi - The Protector Of A Pure Creed
}

Tojiahmedova Muyassar

Lecturer of Namangan State University, Uzbekistan

Copyright: Original content from this work may be used under the terms of the creative commons attributes 4.0 licence.

\section{ABSTRACT}

The great kalam imam and scholar of figh was originally from the village of Moturid in Samarkand (current Jomboy district), whose pseudonym was derived from this village. It is not an exaggeration to say that the Prophet Muhammad (peace be upon him) prophesied about our great countryman, Imam Moturidi, who devoted his life and knowledge to maintain the pure faith of Muslims around the world.

\section{KEYWORDS}

The imam of kalam, the scholar of fiqh, the path of Moturidia, "renewal", heresies and superstitions, wrong interpretations and false lies, the imam of Hidoyat path and mutakallims.

\section{INTRODUCTION}

Abu Mansur al-Moturidi is a founder of the Moturidiya route, one of the two major Sunni beliefs. Little is known about his life. His full name is Abu Mansur Muhammad ibn Muhammad ibn Mahmud al-Hanafiy alMoturidi as-Samarqandi. The great kalam (the study of Islamic doctrine) imam and scholar of figh (a section of Islamic law) was originally from the village of Moturid in Samarkand (current Jomboy district), whose pseudonym was derived from this village. Abu Mansur alMoturidi received his first education in this village and then continued his education in Samarkand, the religious and educational center of Movoraunnahr at that time. AlMoturidi's time coincides with the time of the 
Samanids. Samarkand was originally the capital of this state, and then, at the end of the 9th century, the capital city was moved to Bukhara. Regardless of that, Samarkand remained the economic and cultural center of Movorounnahr along with Bukhara.

\section{MATERIALS AND METHODS}

There is no clear information about Abu Mansur al-Moturidi's birth date. He passed away in Samarkand in 944-945 and was buried in the cemetery named Chokardiza on the outskirts of the city. Some sources state that he was educated at the al-Ayazi madrassah in Samarkand. Al-Moturidi considered Nasr ibn Yahyo al-Balhi, Muhammad ibn al-Fadl in the belief of Imam A'zam, and Abu Bakr Ahmad alJuzjoni, Abu Nasr Ahmad al-lyodi as his mentors.

It is not an exaggeration to say that the Prophet Muhammad (peace be upon him) had prophesied about our great countryman Imam Moturidi, who devoted his life and knowledge to maintain the pure faith of Muslims around the world. Nabii (peace be upon him) said: "Allah sends a mujaddid (a man who renews religion) who renews your religion at the beginning of every hundred years".

The meaning of the "Renewal" in the hadith is not to change the rules and principles of religion, but to purify itself from the various superstitions, heresies, wrong interpretations and false lies that have entered it.

Historians search for answer to the question: "Which of the previous Islamic scholars agrees with this hadith?". According to it, the scholars agreed that Umar ibn Abdul Aziz, born at the beginning of the first hundred years of the Prophet's death, agrees with this hadith.

Umar ibn Abdul Aziz lived between 62 - $101 \mathrm{AH}$ (680 - 719 AD). Umar ibn Abdulaziz was one of the most educated people of his day and ruled the entire Islamic world between $99-101 \mathrm{AH}$. During this short two-year reign, he overthrew all the heresies and superstitions that had been made by the rulers of Bani Umayya before him.

The Harmony Karmatis repeatedly attacked the caravans of pilgrims who had come to perform Hajj, seizing their food and drinking water, leaving them helpless in the desert. These pilgrims would die without food, water, hunger and thirst in the desert. Their aim was to mislead all sincere Muslims and carry out their disgusting ideas. Ismail ibn Ahmed AlSamani was the King in our country at that time, and the people were severely oppressed by the Rafizis. In such a difficult situation, Allah cast Imam Moturidi out of Movarounnahr, Abu al-Hasan Al-Ash'ari from Baghdad, and Abu Ja'far At-Tahavi from Egypt as "Mujaddidul umma." These scholars, without seeing each other, established the path "Ahli sunna val jamoa" of belief. This path is still in keeping the Islamic Ummah on a pure religion.

Imam Moturidi's life and work shows that in the 3 rd century $\mathrm{AH}$, the enemies of religion tried to disrupt Islamic education. They tried to change the verses of the Qur'an and the pure faith of Muslims. But their efforts were inefficient. Allah says that He will protect His Word until the Day of Judgment: "Verily, it is We Who have sent down the Zikr (Koran), and We preserve it" (Surat al-Hijr, Verse 9). When these efforts fail, the mischief-makers include distorting the Qur'an and breaking the hadiths, which is the second basis of Islamic 
education. Unfortunately, they had some success in this regard. They led the verses in the Qur'an to their own ends and fabricated various hadiths on different topics. Thus they tried to mislead the simple Muslim people. Hazrat Imam Moturidi did much to help the Islamic Ummah in such a difficult situation.

\section{RESULTS AND DISCUSSIONS}

Saying a non-praying Muslim as a disbeliever without hesitation, he issued a fatal denial to the various sects that regarded their blood, soul, and property as honest. That is to say: "If a man says "La ilaha illalloh, Muhammadan Rasululloh", he is a "Muslim" whether he prays or not" as he told and gave the following hadith as a proof for this sentence: The Prophet, may Allah bless him and grant him peace, said that whoever says La ilaha illalloh, he will enter the Heaven. For this great service, Hazrat Imam Moturidi was honored by Muslims with such titles as "Imam al-Huda" and "Ahl al-Sunnah of Musahhihu".

Al-Moturidi became interested in the issues of fiqh and kalam, improved his knowledge by taking lessons from the scholars of the Hanafi sect. During this time, he had discussions and kept in touch with many famous scholars and philosophers. He wrote works in this area throughout his life. There is some information given about al-Moturidi and his works in the book named "Katoib ul-a'lom al-axyor fi taboqot va mashaoyix mazahab an-Nu'mon" ("The book about famous scholars of fiqh and sheikhs of Nu'man sect") by Mahmud ibn Sulaymon al Kafavi (passed away in 1582). The names of the following books are mentioned: "Kitab Tavhid" ("The book of isolation of the scholar”), “Kitab Maqomat”, “Kitab rad avomil lil adila lil kabiy" ("the book devoted to refutation of the beginning of Kaba”), “Kitab bayon va hum ul-mu'tazila" ("the book about the wrongdoings of Mu'tazila and not to be afraid of them"), "Kitab Ta'vilot al-Qur'on" ("The Book of Quranic Interpretation"). However, according to "Kashf az-zunun anasomil kutub va-l-funun" ("Eliminating suspicion on the names of books and subjects") by Hoji Halifa (1609-1659), Abu Mansun al-Moturudi also had books called " $\mathrm{Ma}$ hazi ash-shari'a" ("Shariat asoslari sarasi"), "Kitab al-jadal" ("The book about dialectics"), Besides, al-Moturudi's "Kitab al-usul" ("The book of methodology of religious education") is also known. Many of Abu Mansur alMoturidi's works have not reached to this date and the ones which we have are kept in the libraries and manuscript funds of mainly foreign countries. Al-Moturidi's book " Kitab Tavhid", which is considered very delicate in the Islamic world, has reached to our date and it was published by Fathulloh Hulif in 1970. He studied the writings of the founders of the four main Sunni schools of thoughts of Islam and wrote a book on fiqh and kalam. This is named al-Moturudi's “Ta'vilot ahli sunna” or "Ta'vilot al-Qur'on". In his work, Al-Moturidi attempts to refute conflicting views against Sunni doctrine and acted relying on the views of Abu Hanifa. This book is currently kept in Fund of the Institute of Oriental Studies named after Abu Rayhan Beruni of the Academy of Sciences of the Republic of Uzbekistan. The first volume of the "Ta'vilot" was published in Cairo in 1971 by Ibrahim Avadain and As-Said Avadain. This single work by Al-Moturidi laid the foundations of many scholars in the course of history and gave impetus to their work. One of these is the commentary by Aladdin Abu Bakr Muhammad ibn Ahmad as-Samarqandi. It is called "Sharq ta'vilot ahpi as-sunna" and its two copies are kept in the Institution Fund. At the same time, 
there are several fake works written under the name of al-Moturidi.

Al-Moturidi is considered one of the most prominent scholars in Islamic science of his time, and has been widely recognized by scholars of the Muslim world and is still respected in various religious works. $\mathrm{He}$ is also known as "Imam al-Huda" and "Imam almutakallimin" (Imam of the Path of Islam and the Imam of the Mutakallimin). Movarounnahr and Central Asian people gave the world scholars who are known throughout the Muslim world as al-Moturidi in religious sciences together with world-famous figures and thinkers on various fields such as philosophy, natural sciences, literature and art.

As the President of the Republic of Uzbekistan Shavkat Mirziyoev has said - "We have a great history that can be admired. We have great ancestors who deserve admiration and I believe, may God will, we will have a great future which deserves for admiration!"

\section{CONCLUSION}

Sheikh Abdullah Mustafa Muraghi described Imam Moturidi as a scholar with strong evidence and arguments, who was able to provoke the enemy, who defended the Muslim faith and rejected the doubts of the misguided mulhids. Our people will never go astray if we hold on to the pure religious teachings of Imam Motouridi and convey it to the younger generation.

\section{REFERENCES}

1. Mirzioev Sh.M. We build our great future with our brave and noble people. - Tashkent.: 2018. - P. 482.
2. "Stars of Enlightenment". Press House of national heritage named after Abdulla Qodiriy, Tashkent, 1999.

3. Yusupovich, K. S. (2020). The Emergence of Religious Views Is Exemplified By The Southern Regions. The American Journal of Social Science and Education Innovations, 2(10), 143145.

4. http://www.manaviyat.uz/post/view/22 8

5. http://ertaklar.uz/uz/sharqmutafakkirlarining-farzand-tarbiyasihaqidagi-fikrlari/

6. http://www.muslim.uz/ 